\title{
Pendekatan Psikologi dan Religi dalam Meningkatkan Kebahagiaan Lansia di Dinas Sosial UPT Panti Sosial Tresna Werdha Magetan Asrama Ponorogo
}

\author{
Fatakhul Huda, Siti Khusnul Faizah \\ Institut Agama Islam Riyadlotul Mujahidin Ngabar (IAIRM) Ponorogo \\ fatakhul17@gmail.com,sitikhusnulfaizah@gmail.com
}

\begin{abstract}
In general, the elderly who have entered the age of 65 years experienced a reduction in various factors. Especially in an increasingly modern society as a result of increasingly sophisticated technology, adults were increasingly busy with their work so that they lack the time to pay attention to their own families, including their elderly parents. providing assistance to the elderly was not easy. It took a mentor who was able to understand the problems experienced by the elderly. In this case, the approach to them was very much needed that approach was a psychological approach and religious approach. Psychological approach was done so that we knew the problems they face, what they felt, what they want and what they needed psychologically. Religious approach was used so that they could find the peace of life at the end of their time. Especially the elderly who physically and psychologically have suffered setbacks in many ways compared to when they were young.

In Ponorogo there was one social institution that takes care of elderly people who were neglected or were left by their families. The social home was given the name Tresna Wredha Magetan Ponorogo hostel. In this orphanage the elderly were given activities by the administrators, they are brought closer to religious materials in an effort so that they can remember the ultimate goal of life which is to seek God's blessing not only the luxury of the world alone. besides that they are also psychologically approached so that they could divert their loneliness so that they could still found happiness in their old age.

Tresna Wredha Social Institution Ponorogo hostel continued to hold positive activities where the activities were carried out in accordance with their abilities, interests and talents (elderly) so that they could actualize their potential through useful activities.
\end{abstract}

\section{Keywords: Psychology and Religion, Elderly Happiness}

\begin{abstract}
Abstrak
Pada umumnya lansia yang sudah memasuki usia 65 tahun lebih banyak mengalami pengurangan dalam berbagai faktor. Apalagidalam masyarakat yang makin modern sebagai dampak kemajuan teknologi yang makin canggih, orang dewasa makin sibuk dengan pekerjaan mereka sehingga kekurangan waktu untuk memberikan perhatian kepada keluarga mereka sendiri, termasuk kepada orang tua mereka yang lanjut usia.memberikan bantuan kepada lansia bukanlah hal yang mudah. Dibutuhkan seorang pembimbing yang mampu memahami masalah yang dialami oleh para lanjut usia Dalam hal ini, pendekatan kepada mereka sangatlah dibutuhkan pendekatan itu adalah pendekatan psikologi dan pendekatan religi. Pendekatan psikologi dilakukan agar kita tau permasalahan-permasalahan yang mereka hadapi, apa yang mereka rasakan, apa yang mereka inginkan dan apa yang mereka butuhkan secara psikologis. Pendekata religi di gunakan agar mereka bisa menemukan ketenangan hidup di akhir masanya.Apalagi para lanjut usia yang secara fisik dan psikis telah mengalami kemunduran dalam banyak hal dibandingkan ketika masih muda.

Di Ponorogoterdapat salah satu panti sosial yang merawat para lansia yang terlantar ataupun dititipkan oleh keluarga mereka. Panti sosial itu diberi nama Tresna Wredha Magetan asrama Ponorogo. Di panti ini para lansia diberikan kegiatan-kegiatan oleh para pengurus, mereka di dekatkan dengan materi-materi keagamaan sebagai upaya agar mereka
\end{abstract}


bisa ingat pada tujuan akhir hidupnya yaitu mencari ridlo Allah bukan hanya kemewahan dunia semata. selain itu mereka juga di dekati secara psikologis agar mereka bisa mengalihkan rasa sepi mereka agar mereka tetep bisa menemukan kebahagiaan dimasa tuanya.

Panti Sosial Tresna Wredha Magetan asrama Ponorogo senantiasa mengadakan kegiatan-kegiatan yang positif yang mana kegiatan yang dilakukannya ini sesuai dengan kemampuan, minat dan bakat mereka (lansia) sehingga mereka dapat mengaktualisasikan potensi diri melalui aktivitas yang bermanfaat.

\section{Kata Kunci: Psikologi dan Religi,Kebahagiaan Lansia}

\section{Pendahuluan}

Lansia merupakan periode penutup dalam rentang hidup seseorang yaitu periode dimana seseorang telah beranjak jauh dari periode terdahulu yang lebih menyenangkan atau beranjak dari waktu yang penuh manfaat. Pada umumnya lansia yang sudah memasuki usia 65 tahun lebih banyak mengalami pengurangan dalam berbagai faktor. Secara fisik mengalami penurunan stamina atau daya tahan tubuh, secara mental menurun ditandai tidak tahan lama jika berfikir lama ketika masa dewasa dan sering lupa, secara sosial mulai berkurang intensitas sosialisasi dalam bermasyarakat karena sudah mulai lemah.

Disamping itu Kini, dalam masyarakat yang makin modern sebagai dampak kemajuan teknologi yang makin canggih, orang dewasa makin sibuk dengan pekerjaan mereka sehingga kekurangan waktu untuk memberikan perhatian kepada keluarga mereka sendiri, termasuk kepada orang tua mereka yang lanjut usia. Bahkan diantara mereka banyak yang menganggap orang tua sebagai beban. Oleh karena itu mereka memutuskan untuk memiliki pembantu khusus atau menempatkan orang lanjut usia di panti jompo.

Dalam kenyataannya, memberikan bantuan kepada lansia bukanlah hal yang mudah. Dibutuhkan seorang pembimbing yang mampu memahami masalah yang dialami oleh para lanjut usia. Dalam hal ini, pendekatan kepada mereka sangatlah dibutuhkan pendekatan itu adalah pendekatan psikologi dan pendekatan religi. Pendekatan psikologi dilakukan agar kita tau permasalahan-permasalahan yang mereka hadapi, apa yang mereka rasakan, apa yang mereka inginkan dan apa yang mereka butuhkan secara psikologis. Pendekata religi di gunakan agar mereka bisa menemukan ketenangan hidup di akhir masanya.Apalagi para lanjut usia yang secara fisik dan psikis telah mengalami kemunduran dalam banyak hal dibandingkan ketika masih muda.

Para lanjut usia yang ada di panti jompo mempunyai ragam permasalahan yang mereka hadapi di masa tua yang awalnya mereka berjaya dimassa mudanya mereka harus menerima sebuah kenyataan untuk hidup dengan penuh keterbatasan apalagi mereka hidup di panti jompo yang jauh dari keluarga jadi mereka akan merasakan kesepian. Seorang konselor sebaiknya mengetahui kondisi yang dihadapi klien, supaya materi yang diberikan sesuai dan tepat pada sasaran.

Di Ponorogo, terdapat salah satu panti sosial yang merawat para lansia yang terlantar ataupun dititipkan oleh keluarga mereka. Panti sosial itu diberi nama Tresna Wredha Magetan asrama Ponorogo. Di panti ini para lansia diberikan kegiatan-kegiatan oleh para pengurus, mereka di dekatkan dengan materi-materi keagamaan sebagai upaya agar mereka bisa ingat pada tujuan akhir hidupnya yaitu mencari ridlo Allah bukan hanya kemewahan dunia semata. selain itu mereka juga di dekati secara psikologis agar mereka bisa mengalihkan rasa sepi mereka agar mereka tetep bisa menemukan kebahagiaan dimasa tuanya. 
Materi Bimbingan dapat berupa pendalaman tentang aqidah, akhlak maupun syariat. Selain hal itu, materi yang diberikan kepada lanjut usia sebaiknya dilakukan secara berulangulang, mengingat kliennya adalah lanjut usia yang sudah berkurang daya konsentrasinya dan pemahaman tentang agama yang tidak merata.

Panti Sosial Tresna Wredha Magetan asrama Ponorogo adalah salah satu panti sosial tempat penampungan lansia (lanjut usia) yang mana didirikan guna membantu pemerintah dalam upaya penanggulangan penyandang masalah kesejahteraan sosial.

Panti Sosial Tresna Wredha Magetan asrama Ponorogo senantiasa mengadakan kegiatan-kegiatan yang positif yang mana kegiatan yang dilakukannya ini sesuai dengan kemampuan, minat dan bakat mereka (lansia) sehingga mereka dapat mengaktualisasikan potensi diri melalui aktivitas yang bermanfaat.Kegiatan lainnya yaitu berupa bimbingan keagamaan.Kegiatan bimbingan keagamaan ini bertujuan selain untuk menambah pengetahuan tentang agama kepada mereka (lansia) bimbingan keagamaan ini diberikan kepada para lansia agar mereka senantiasa lebih mendekatkan diri kepada Allah SWT dan untuk mengembangkan potensi dirinya sehingga mereka mampu menyelesaikan masalahmasalah yang dihadapinya terlebih agar mereka senantiasa lebih termotivasi untuk dapat melakukan aktivitas yang positif di sisa hidupnya.

Bimbingan keagamaan di panti sosial Tresna Wredha Magetan asrama Ponorogo dilakukan secara bertahap.Hal ini dilakukan supaya bimbingan keagamaan sesuai dengan harapan dan tujuan panti tersebut. Seorang pembimbing melakukan persiapan sebelum melaksanakan bimbingan keagamaan seperti, menyiapkan materi yang akan di sampaikan. Bimbingan keagamaan dilaksanakan setiap hari Senin, Jum'at dan Sabtu dengan durasi waktu satu jam. Kegiatan bimbingan keagamaan dilakukan di aula panti dengan menggunakan beberapa metode yang telah disiapkan oleh pembimbing. Namun disisi lain maksimalnya usaha yang dilakukan pembimbing dihadapkan kepada berbagai kendala yang ada pada lanjut usia, seperti kondisi fisik yang telah menurun, daya ingat dan daya konsentrasi yang sudah mulai lambat karena faktor udzur..

Masalah yang terjadi di panti sosial Tresna Wredha Magetan asrama Ponorogo dari segi bimbingan keagamaan banyak para lansia yang kurang termotivasi untuk mengikuti bimbingan keagamaan. Hal ini ditandai dengan adanya beberapa lansia yang jarang mengikuti serangkaian aktivitas dari bimbingan keagamaan yang disuguhkan padahal mereka mengetahui akan pentingnya bimbingan keagamaan bagi kehidupan mereka. Sehingga banyak lansia yang belum bisa membaca al-Qur'an, belum mengetahui bacaan shalat, bahkan untuk berzikirpun mereka belum lancar.Hal itu disebabkan karena motivasi belum tertanam di dalam diri para lansia. Padahal mereka sering mengeluh akan problematika yang terjadi pada diri mereka. Oleh karena itu pendekatan secara psikologi sangat di butuhkan untuk memunculkan suatu semangat dalam diri para lansia. Agar mereka bisa menemukan ketenangan batin dan kedamaian di masa akhir dari kehidupan mereka.

\section{Pendekatan psikologi}

Psikologi berasal dari kata Yunani "psyche" yang artinya jiwa. Logos berarti ilmu pengetahuan. Jadi secara etimologi psikologi berarti : "ilmu yang mempelajari tentang jiwa, baik mengenai gejalanya, prosesnya maupun latar belakangnya". Namun pengertian antara ilmu jiwa dan psikologi sebenarnya berbeda atau tidak sama (menurut Gerungan) karena :

1) Ilmu jiwa adalah : ilmu jiwa secara luas termasuk khalayan dan spekulasi tentang jiwa itu.

2) Ilmu psikologi adalah ilmu pengetahuan mengenai jiwa yang diperoleh secara sistematis dengan metode-metode ilmiah.

Pengertian jiwa dengan nyawa adalah berbeda. Nyawa adalah daya jasmaniah yang adanya tergantung pada hidup jasmani dan menimbulkan perbuatan badaniah (organic 
behavior) yiatu perbuatan yang ditimbulkan oleh proses belajar, misal : insting, refelks, nafsu dan sebagainya. Sedang jiwa adalah : daya hidup rohaniah yang bersifat abstrak yang menjadi penggerak dan pengatur bagi sekalian perbuatan-perbuatan pribadi (personal behavior) dari hewan tingkat tinggi hingga manusia. Perbuatan pribadi adalah perbuatan sebagai hasil proses belajar yang dimungkinkan oleh keadaan jasmani, rohaniah dan sosial.

Menurut Aristoteles, jiwa disebut sebagi anima yang terbagi dalam tiga macam jenis yaitu :

1. Anima vegetativa, yaitu anima yang terdapat pada tumbuh-tumbuhan yang mempunyai kemampuan untuk makan, minum dan berkembang biak

2. Anima sensitiva, yaitu anima yang terdapat dalam hewan. Anima ini memiliki kemampuan seperti anima vegetativa juga kemampuan untuk berpindah tempat, mempunyai nafsu, dapat mengamati, mengingat dan merasakan.

3. Anima intelektiva, anima yang terdapat dalam diri manusia. Selain memiliki kemampuan seperti anima sensitiva juga mempunyai kemampuan berpikir dan berkemauanan.

\section{Pendekatan Religi}

Menurut kamus Chaplin bahwa sikap adalah suatu predisposisi atau kecenderungan yang relative stabil dan berlangsung terus menerus untuk bertingkah laku atau untuk bereaksi dengan satu cara tertentu terhadap pribadi lain, objek atau lembaga atau persoalan tertentu.(J.PChaplin, 1995)

Menurut M. Ngalim Purwanto, Sikap atau attitude adalah suatu cara bereaksi terhadap suatu perangsang, suatu kecenderungan untuk bereaksi dengan cara tertentu terhadap suatu perangsang atau situasi yang terjadi.(Purwanto, 1990)

Sedangkan religius, kata dasar dari religius adalah religi yang berasal dari bahasa asing religion sebagai kata bentuk dari kata benda yang berarti agama. Menurut Jalaluddin, Agama mempunyai arti: Percaya kepada Tuhan atau kekuatan super human atau kekuatan yang di atas dan di sembah sebagai pencipta dan pemelihara alam semesta, Ekspresi dari kepercayaan di atas berupa amal ibadah, dan suatu keadaan jiwa atau cara hidup yang mencerminkan kecintaan atau kepercayaan terhadap Tuhan, kehendak, sikap dan perilakunya sesuai dengan aturan Tuhan seperti tampak dalam kehidupan kebiasaan.(Jalaluddin, 2008)

Sedangkan religius, kata dasar dari religius adalah religi yang berasal dari bahasa asing religion sebagai kata bentuk dari kata benda yang berarti agama. Menurut Jalaluddin, Agama mempunyai arti: Percaya kepada Tuhan atau kekuatan super human atau kekuatan yang di atas dan di sembah sebagai pencipta dan pemelihara alam semesta, Ekspresi dari kepercayaan di atas berupa amal ibadah, dan suatu keadaan jiwa atau cara hidup yang mencerminkan kecintaan atau kepercayaan terhadap Tuhan, kehendak, sikap dan perilakunya sesuai dengan aturan Tuhan seperti tampak dalam kehidupan kebiasaan.(Jalaluddin, 2008)

Jadi dapat diketahui bahwa religius merupakan suatu sikap yang kuat dalam memeluk dan menjalankan ajaran agama serta sebagai cerminan dirinya atas ketaatannya terhadap ajaran agama yang dianutnya.

Dari uraian di atas dapat disimpulkan sikap religius adalah suatu keadaan diri seseorang dimana setiap melakukan atas aktivitasnya selalu berkaitan dengan agamanya.Dalam hal ini pula dirinya sebagai hamba yang mempercayai Tuhannya berusaha agar dapat merealisasikan atau mempraktekkan setiap ajaran agamanya atas dasar iman yang ada dalam batinnya.

Dalam ajaran agama islam, religius seseorang tidak hanya dapat diwujudkan melalui aktifitas ritual saja, tetapi juga dilihat dari beberapa dimensi yang lain. Menurut Zuhairini adalah secara umum dasar-dasar agama islam meliputi Aqidah, Syari'ah dan Akhlak.23 Hal 
ini sejalan dengan pernyataan Yusuf Al-Qardhawy yang menyatakan bahwa dalam agama islam memiliki dimensi-dimensi atau pokok-pokok islam yang secara garis besar dibagi menjadi 3 yaitu : Aqidah, Ibadah atau praktek agama atau syari'at dan akhlak.(Qardawi, 1997)

\section{Pengertian Kebahagiaan}

Menurut Seligman(Seligman, 2005) kebahagiaan hidup merupakan konsep yang mengacu pada emosi positif yang dirasakan individu serta aktivitas-aktivitas positif yang disukai oleh individu tersebut.Kebahagiaan hidup ini ditandai dengan lebih banyaknya afek positif yang dirasakan individu dari pada afek negatif.

Selain itu kebahagiaan juga merupakan suatu konsep yang subjektif yang sering dialami oleh setiap individu dari waktu ke waktu sebagai gambaran perasaan atau emosi. Kebahagiaan adalah perasaan suka, senang, gembira yang dirasakan oleh individu dan sumber penyebab munculnya kebahagiaan bagi setiap individu berbeda-beda. Dengan kata lain, hanya orang-orang yang bersangkutan yang dapat mengatakan apakah mereka bahagia atau tidak bahagia dengan kehidupan yang mereka jalani.

Salah satu indikator kebahagiaan antara lain adalah rasa syukur. Beberapa penelitian menyatakan bahwa individu yang merasa bersyukur terhadap kehidupannya dan menunjukkan rasa penghargaan memiliki kebahagiaan yang lebih tinggi (Larsen, 2008).Individu yang menunjukkan rasa syukur dan penghargaan memiliki tingkat Kebahagiaan yang lebih tinggi dari pada mereka yang tidak menunjukkan hal tersebut.

Menurut Khavari (Khavari, 2006) menyebutkan bahwa kebahagiaan terasa tidak hanya ketika mendapatkan apa yang kita inginkan, tetapi juga ketika kita menginginkan apa yang telah kita dapatkan. Ada juga yang mengatakan kebahagiaan adalah secarik rasa yang aneh dan misteri serta mahal yang seseorang tidak mudah untuk mengatakan bahwa dirinya adalah bahagia, sementara orang lain mengatakan bahwa dia adalah orang yang bahagia. Bahagia hanya mudah diucapkan, dirasakan dan dibayangkan oleh orang-orang yang dirinya belum berada pada tempat penyebab kebahagiaan tersebut.

Menurut Bastaman hidup bermakna adalah gerbang menuju kebahagiaan.Ia adalah corak kehidupan yang menyenangkan, penuh semangat, bergairah, serta jauh dari rasa cemas dan hampa dalam menjalani kehidupan sehari-hari.Hal ini terjadi sebagai akibat dari terpenuhinya nilai-nilai dan tujuan hidup yang positif dan benar-benar didambakan. Kehidupan pribadi yang bermakna ditandai oleh adanya aspek-aspek berikut ini pada diri seseorang, yaitu: hubungan antar pribadi yang harmonis, saling menghormati, dan saling menyayangi; kegiatan-kegiatan yang disukai dan menghasilkan karya-karya yang bermanfaat buat orang lain; kemampuan mengatasi berbagai kendala kehidupan dan menganggap kendala ini bukan sebagai masalah, tetapi sebagai peluang dan tantangan; tujuan hidup yang jelas sebagai pedoman dan arahan kegiatan yang dilandasi oleh keimanan yang mantap; rasa humor yang tinggi, yaitu mampu melihat secara humoristis pengalaman-pengalaman sendiri, termasuk pengalaman hidup yang tragis; secara sadar berusaha meningkatkan taraf berpikir; bertindak positif, mengembangkan potensi diri, yang meliputi fisik, mental, emosi, sosial, dan spiritual, secara seimbang, untuk meningkatkan kualitas hidup yang lebih baik dan meraih citra diri yang diidam-idamkan; dan melandasi semua hal yang di atas dengan do'a, ibadah, dan niat yang suci.(HD.Bastaman, 1995)

\section{Faktor-faktor yang mempengaruhi kebahagiaan}

Untuk mengidentifikasi faktor-faktor yang mempengaruhi kebahagiaan bukanlah hal yang mudah.Hal ini disebabkan oleh adanya perbedaan pada setiap individu.Perbedaan tersebut dapat disebabkan oleh perbedaan kepribadian dan lingkungan yang kondusif atau 
yang menyediakan kesempatan individu untuk mencapai kebahagiaan yang dibutuhkan atau yang diinginkan.

Salah satu sumber yang paling penting dari kebahagiaan adalah adanya hubungan pribadi yaitu persahabatan, pernikahan, keintiman, dan dukungan sosial. Seligman (Seligman, 2005) menjelaskan faktor-faktor yang mempengaruhi kebahagiaan yaitu: kehidupan sosial, agama atau religiusitas: orang yang religius lebih bahagia dan lebih puas terhadap kehidupan daripada orang yang tidak religius. Hal ini dikarenakan agama memberikan harapan akan masa depan dan menciptakan makna dalam hidup bagi manusia. Hubungan antara harapan akan masa depan dan keyakinan beragama merupakan landasan mengapa keimanan sangat efektif melawan keputusasaan dan meningkatkan kebahagiaan.

Faktor lain yang menyebabkan kebahagiaan menurut Seligman(Seligman, 2005) yaitu pernikahan. Kebahagiaan orang yang menikah mempengaruhi panjang usia dan besarnya penghasilan, hal ini berlaku bagi pria dan wanita. Selanjutnya yang mempengaruhi kebahagiaan adalah usia.

Berdasarkan uraian di atas dapat disimpulkan bahwa faktor yang menyebabkan individu merasakan kebahagiaan adalah adanya faktor internal, yaitu usia, jenis kelamin, kecerdasan, seks, kesehatan, cinta, kesuksesan, agama dan faktor eksternal diantaranya yaitu komunitas, dukungan sosial, persahabatan, pernikahan, pekerjaan, dan pendidikan.

\section{Komponen Kebahagiaan}

Pada dasarnya, bahagia adalah fitrah atau bawaan alami manusia. Artinya, ia merupakan sesuatu yang melekat dalam diri manusia. Bahagia sudah seharusnya dimiliki oleh setiap manusia, karena menurut fitrahnya, manusia diciptakan dengan berbagai kelebihan dan kesempurnaan.Manusia adalah makhluk yang paling baik dan sempurna dibanding dengan makhluk lainnya. Hal ini telah dinyatakan oleh Allah dalam Al Qur'an (Q.S. Al-Isra': 70) sebagai berikut:

"Dan sungguh Kami telah memuliakan anak cucu Adam dan Kami angkat mereka di daratan dan lautan, dan Kami telah memberikan rezeki yang baik kepada mereka, dan Kami telah lebihkan mereka dari makhluk-makhluk lain yang telah Kami ciptakan dengan kelebihan yang sempurna".(Fuad, 2015)

Pada saat materialisme menjadi panglima, di mana kekayaan, jabatan, dan ketenaran menjadi dewa yang diagung-agungkan, kematian bunuh diri seorang aktor hebat peraih Oscar (Robin William) adalah sebuah tragedi kemanusiaan.Kenyataan yang mengenaskan ini meniscayakan adanya redefinisi terhadap ukuran kesuksesan dan kebahagiaan.Dua komponen yang selama ini dianggap sebagai ukuran utama kesuksesan, yaitu kekayaan dan kekuasaan, perlu dilengkapi dengan hal-hal yang lebih mendasar lagi. Ariana Huffington menawarkan empat elemen kesuksesan, yaitu: kesehatan lahiriah-batiniah (well-being), ketakjuban (wonder), kearifan (wisdom), dan sikap memberi (giving). Dalam ukuran baru ini, sukses harus berbanding lurus dengan kebahagiaan. Sukses haruslah sebangun dengan kebermaknaan hidup.Jadi, persoalan setiap manusia adalah bagaimana menemukan kebahagiaan hidup yang sesungguhnya dengan mengisinya dengan hal-hal yang bermakna.

Kebahagiaan memiliki beberapa komponen, yaitu:

a. Afek Positif dan Afek Negatif

Afek positif dan afek negatif menggambarkan pengalaman utama dari situasi atau kejadian yang terus terjadi dalam kehidupan manusia. Penilaian afek terhadap situasi tertentu ikut mempengaruhi penilaian individu akan kesejahteraan subjektifnya. Dengan mengetahui tipe kecenderungan reaksi yang dialami individu, kita dapat memperoleh pemahaman tentang cara individu menilai kondisi dan kejadian yang terjadi dalam hidupnya. 
Evaluasi afek terdiri dari emosi dan mood, dimana emosi bersifat lebih sementara karena merupakan respon situasi, sedangkan mood memiliki rentang yang lebih lama dari pada emosi.Orang yang bahagia adalah orang yang jarang mengalami afek negatif dan sering mengalami afek positif.

1) Afek positif merupakan perasaan-perasaan positif yang ada dalam diri individu seperti: afek tertarik, bergairah, kuat, antusias, bangga, waspada, terinspirasi, penuh tekad, penuh perhatian dan aktif.

2) Afek negatif merupakan perasaan-perasaan negatif yang ada dalam diri individu seperti: afek tertekan, kecewa, bersalah, takut, memusuhi, gampang marah, malu, gelisah, gugup dan khawatir.

b. Kepuasan Hidup

Kepuasan hidup didefinisikan sebagai penilaian global tentang kualitas hidup inidividu.Individu dapat menilai kondisi hidupnya, mempertimbangkan pentingnya kondisi-kondisi ini dan mengevaluasi kehidupan mereka pada skala yang berkisar dari tidak puas sampai puas. Berbeda dengan afek positif dan negatif yang merupakan komponen afektif dari kebahagiaan, kepuasan hidup merupakan komponen kognitif karena melibatkan proses kognitif dalam mengevaluasi kejadian yang terjadi dalam hidup.

Dari penjelasan di atas maka dapat ditarik kesimpulan bahwa komponen dari kebahagiaan ada tiga yaitu afek positif yang menggambarkan perasaan positif yang ada pada diri individu, afek negatif menggambarkan perasaan negatif yang ada pada diri individu dan kepuasan hidup yang melibatkan proses kognitif dalam mengevaluasi kejadian yang terjadi dalam hidup.

\section{Pengertian Lansia}

Usia lanjut adalah fase menurunnya kemampuan akal dan fisik, yang di mulai dengan adanya beberapa perubahan dalam hidup. Sebagaimana di ketahui, ketika manusia mencapai usia dewasa, ia mempunyai kemampuan reproduksi dan melahirkan anak. Ketika kondisi hidup berubah, seseorang akan kehilangan tugas dan fungsi ini, dan memasuki selanjutnya, yaitu usia lanjut, kemudian mati. Bagi manusia yang normal, siapa orangnya, tentu telah siap menerima keadaan baru dalam setiap fase hidupnya dan mencoba menyesuaikan diri dengan kondisi lingkunganya (Martono, 2004).

Pengertian dan pengelolaan lansia menurut Undang -Undang Republik Indonesia Nomor 13 Tahun 1998 tentang lansia sebagai berikut :

a. Lanjut Usia adalah seseorang yang telah mencapai usia 60 tahun (enam puluh) tahun keatas.

b. Lanjut Usia Potensial adalah lanjut usia yang masih mampu melakukan pekerjaan dan/atau kegiatan yang dapat menghasilkan barang dan/atau jasa.

c. Lanjut Usia Tidak Potensial adalah lanjut usia yang tidak berdaya mencari nafkah sehingga hidupnya bergantung pada bantuan orang lain.

\section{Proses Menua}

Proses menua adalah suatu proses menghilangnya secara perlahan-lahan kemampuan jaringan untuk memperbaiki diri atau mengganti dan mempertahankan fungsi normalnya, sehingga tidak dapat bertahan terhadap infeksi dan memperbaikinya kerusakan yang diderita. Proses menua merupakan proses yang terus-menerus secara alamiah dimulai sejak lahir dan setiap individu tidak sama cepatnya. Menua bukan status penyakit tetapi merupakan proses berkurangnya daya tahan tubuh dalam menghadapi rangsangan dari dalam maupun dari luar tubuh. Dengan begitu manusia secara progresif akan kehilangan daya tahan terhadap infeksi dan akan menumpuk makin banyak distorsi 
metabolik dan stuktural yang disebut sebagai penyakit degenerative seperti, hipertensi, aterosklerosis, diabetes militus dan kanker yang akan menyebabkan kita menghadapi akhir hidup dengan episode terminal yang dramatik seperti strok, infark miokard, koma asidosis, metastasis kanker dan sebagainya(Martono, 2004).

\section{Batasan Lanjut Usia}

Batasan umur lansia menurut organisasi kesehatan dunia (WHO) lanjut usia meliputi: 1). Usia pertengahan (middle age), ialah kelompok usia 45 sampai 59 tahun. 2). Lanjut usia (elderly) $=$ antara 60 sampai 74 tahun. 3). Lanjut usia tua (old) $=$ antara 75 sampai 90 tahun. 4). Sangat tua (very old) $=$ diatas 90 tahun.

Sedangkan menurut DepKes RI tahun 1999, umur lanjut usia terbagi 3 yaitu;(Hardiwinoto, 1999)

a. Usia pra senelis atau Virilitas adalah seseorang yang berusia 45-49 tahun

b. Usia lanjut adalah seseorang yang berusia 60 tahun atau lebih

c. Usia lanjut resiko tinggi adalah seseorang yang berusia 70 tahun atau lebih atau dengan masalah kesehatan. 


\section{Bibliography}

Fuad, M. (2015). Psikologi kebahagiaan manusia. Jurnal Komunika, 1.

Hardiwinoto, S. T. (1999). Panduan Gerontologi Tinjauan Dari Berbagai Aspek. Jakarta: PT Gramedia Pustaka Utama.

HD.Bastaman. (1995). Intregrasi Psikologi Dengan Islam, Menuju Psikologi Islami. Yogyakarta: Pustaka pelajar.

J.PChaplin. (1995). Kamus Lengkap Psikologi. Jakarta: PT Raja Grafindo Persada.

Jalaluddin. (2008). Psikologi Agama Memahami Prilaku Keagamaaan Dengan Mengaplikasikan Prinsip-Prinsip Psikologi. Jakarta: PT Raja Grafindo Persada.

Khavari, K. (2006). The Art Of Happiness (Mencipta Kebahagiaan dalam Stiap Keadaan). Jakarta: PT.Serambi Ilmu.

Larsen, J. \&. (2008). Is happiness having what yo want, wanting what you have,or both? psychological science, 371.

Martono, D. \&. (2004). Buku ajar geriatri (Ilmu kesehatan usia lanjut). Jakarta: FKUI.

Purwanto, M. (1990). Psikologi Pendidikan. Bandung: PT.Remaja Rosda Karya.

Qardawi, Y. A. (1997). Pengantar Kajian Islam. Jakarta: Pustaka Al Kausar.

Seligman, M. (2005). Menciptakan Kebahagiaan dengan Psikologi Positif (Authentic Happiness). Bandung: PT.Mizan Pustaka. 